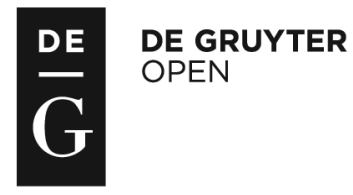

Administration, vol. 65, no. 3 (2017), pp. 17-39

doi: 10.1515/admin-2017-0022

\title{
Gender budgeting in Scotland: A work in progress
}

\author{
Angela O'Hagan \\ Glasgow Caledonian University
}

\begin{abstract}
After almost twenty years of devolved government in Scotland, during which gender analysis of the budget process has been advocated, this article explores the discursive framing of gender budgeting and progress towards implementation. Charting historical and conceptual developments, from feminist economics and feminist institutionalist perspectives, the article highlights the significance of engaged political, civil society and policy actors; the need for clear conceptual framing; and the time it has taken for limited progress to embed. Conscious of financial constraints and economic commitments, including an ambitious extension of publicly funded childcare, the discussion highlights the positive advances in integrating gender equality into economic analysis. It offers insight into the institutional arrangements and advocacy that have maintained pressure for the Scottish budget process to be subject to effective scrutiny and to function as a key driver of gender equality.
\end{abstract}

Keywords: Gender, budget process, Scotland, policy

\section{Introduction}

Over the lifetime of the Scottish Parliament there has been a sustained attempt to embed gender analysis in the budget process and, by extension, across economic policy and the approach to spending 
decisions of successive governments. Framing gender budgeting as a meta policy for both gender equality and economic policy follows two core propositions of gender budgeting. Firstly, the budget is not a neutral exercise as the decisions it contains have gendered consequences - intentional and unintentional - as well as being informed and influenced by gendered analysis. Secondly, as the principal expression of a government's priorities, the budget is a political tool and process, not a straightforward technical exercise.

The Scottish Women's Budget Group (SWBG) and others have made these arguments consistently during the good times of higher spending and the worsening times of UK Government budget cuts. They have also been made in the context of Scottish Government decisions in relation to funding local government and other public services, and the decline in the Scottish budget in recent years following the reduction in public spending through UK Government austerity budgets.

Following a brief outline of the Scottish public finances, the article introduces the concept of gender budgeting and discusses its transformative potential. Introducing a Framework of Favourable Conditions (FFC), it unpacks the introduction of gender budgeting as a policy response to women's unequal economic status, reflecting its feminist transformative intent. It then isolates post-2007 significant discursive changes that shifted from equality proofing to embedding equality budgeting in economic objectives, including economic growth. In exploring the changed dynamic the article focuses on political opportunities and critical actors, in particular the role of SWBG and later the Equality Budgeting Advisory Group, but also the engagement of parliamentarians. Analysing discursive shifts, it highlights the move towards using medium-term economic frameworks, such as government spending plans and economic strategies, as a vehicle for advancing gender equality. The conclusion reflects that the Scottish model, while limited, is built on a feminist economics perspective and highlights the importance of ensuring that an equalities mainstreaming approach does not render gender analysis almost invisible in economic policy.

\section{Public finance context}

Following a period of significant growth, from a total budget of $£ 16.3$ billion at the inception of the parliament in 2000 (Scottish Executive, 2000), the value of the Scottish budget has fallen in recent years, from a peak of $£ 34.76$ billion in 2009-10 (Scottish Government, 2008) to a 
projected $£ 27.5$ billion by 2020. In 2010 the Independent Budget Review (Scottish Government, 2010b) projected that it would take up to fifteen years to recover spending levels following a 3.3 per cent yearon-year reduction up to 2014, and an overall contraction in the Scottish budget of 12.5 per cent by 2014-15 compared with 2010-11. The budget for 2017-18 was set at $£ 31.46$ billion with further significant decreases anticipated up to 2020, representing a real-terms cumulative change of 7.2 per cent from 2010-11 to 2020 (Scottish Government, 2016, p. 3).

In addition to these significant changes in Scotland's finances, the political context has also changed substantially. One outcome of the Scottish independence referendum in 2014 was the devolution of further powers in social security (spending) and expanded taxation (revenue) powers. Devolved measures included a series of social security benefits for disabled people and carers, with a value of some $£ 2.8$ billion, and significant powers to set income tax rates and bands. Other devolved revenue measures included Land and Buildings Transaction Tax and Landfill Tax, introduced in 2015. Under the fiscal framework there has been a 'material change in the financial responsibility of the Scottish Parliament' (Scottish Government, 2017). From financial year 2017-18, income tax in Scotland, an estimated $£ 11$ billion in revenue, will be raised and spent by the Scottish Government. The Scottish Rate of Income Tax basic rate has been set at 20 per cent, the same rate as the UK. However, the Scottish Government has decided for the moment not to implement UK government policy to cut the higher $40 \mathrm{p} / £ 1$ rate in Scotland. These new powers are happening in the increasingly uncertain context of 'Brexit' and the political instability following the June 2017 UK general election.

\section{Understanding gender budgeting}

Gender budgeting aims to raise awareness of the different impacts on women and men of publicly funded policies and programmes at national, sub-national and local government levels and within public authorities, such as universities or health boards. At its core, gender budgeting challenges embedded 'gender-blind' practices within gendered institutions (Acker, 1992; Chappell, 2006; Lovenduski, 1998) that reproduce male bias in decision-making and analysis (Elson, 1995), and subsequently result in gendered budget processes and outcomes. 
A principal aim of gender budgeting is to integrate gender analysis into economic policy, government spending and revenue proposals. Gender analysis of the policy and resource allocation process in the budget means examining how budgetary allocations affect the economic and social opportunities of women and men, and restructuring revenue and spending decisions to eliminate unequal gendered outcomes. Gender budgeting does not mean separate budgets for women and men, but rather it is a critical review of resource allocation to identify potential differential impacts on women and men, and to understand the contexts in which those differences arise.

An important goal of gender budgeting, linking gender equality policy and macroeconomic policy by ensuring greater consistency between economic goals and social commitments, is particularly germane in the Scottish context. This ambition of gender budgeting and the interlinking goals have structured SWBG's approach since its inception in 1999 in its engagement with politicians, civil servants and parliamentarians, and in responding to emerging government policy responses.

Specific factors have combined to create a series of favourable conditions for the adoption and implementation of gender budgeting in Scotland (O'Hagan, 2015). This article considers the extent to which those conditions have existed and endure, the changing discourses around gender and equality budgeting, the principal actors involved in promoting gender budgeting, and the extent to which, and the specific areas in which, it has been implemented.

\section{Transformative potential of gender budgeting}

The 'transformative nature and project of feminism' (Figart, 2005) underpin gender budgeting as an attempt to transform macroeconomics, aiming to make gender visible in economic and other policy domains (Himmelweit, 2002). This radical conjoining of feminist economics and mainstreaming gender analysis challenges established policy processes and practices to foster a 'fundamental reconsideration of the foundations of economic theory and policy making' to deliver a 'transformatory' impact (Rubery, 2005, p. 2). Gender budgeting is rooted in the theoretical and conceptual foundations of feminist economics and feminist political science, conceptualised as strategically 'broadening gender mainstreaming' to include macroeconomic processes (Çağatay et al., 2000, p. 18) such as fiscal and budgetary policy, public finance management and financial planning. 
Exemplifying 'feminist politics in action' (Sharp, 2003), gender budgeting is a form of direct feminist engagement with the state. Sharp \& Broomhill (2002) offered an early categorisation of government-led (inside) work that can be applied to current activity such as that in Austria or the autonomous government of Andalucía, and of 'outside' government initiatives from civil society such as Poland, the UK and Scotland, or donor-led (outside) developments such as those in Ukraine funded by UN Women or experiences in Italy funded with European Structural Funds.

Founded in 1999/2000 SWBG is a voluntary organisation of women activists, academics and practitioners in gender politics and policy. It has maintained a presence and central role in advocating for integrating gender analysis in the budget process and for a transformation in public policy that recognises and acts on the centrality of care and the significance of women's paid and unpaid contribution to social and economic well-being. SWBG has consistently pressed for improved data availability and analysis to inform policy and budget decisions, acknowledgement of the budget as a key policy tool for the advancement of gender equality objectives across policy domains, and the embedding of analytical and process tools to support the development of gender-aware budgets (McKay \& Gillespie, 2007).

SWBG is a distinctive outside government initiative, securing early access to government and parliamentary institutions to push gender budgeting on to the political agenda as a transformative approach to public policy decision-making. From its early access to the newly formed devolved government institutions through to influencing institutional arrangements to support gender budgeting, SWBG's history and ways of working reflect the context of a small and permeable polity in Scotland. SWBG has operated to maximise the opportunities of the political dynamics and dimensions of a small country that is closely networked at elite and advocacy levels. This is a distinctive aspect of the Scottish experience compared to other subnational and national attempts such as Spain, Austria, Iceland, Italy and Germany (see O'Hagan \& Klatzer, forthcoming).

\section{Gender budgeting as feminist policy change}

Gender budgeting was initially presented in Scotland as a strategic form of feminist policy change, consistent with the desire for a new politics in the lead-in to the first round of Scottish devolution in 1999. From 2000 to 2017 there has been a noticeable shift in the framing of 
gender budgeting as the political environment has altered over time with different emphases from political parties and opportunities for revision and realignment of gender equality approaches.

The FFC presented in Figure 1 (O'Hagan, 2015) supports analysis and understanding of these shifts and the distinct phases of policy change in Scotland, and is generalisable to other contexts. Initially developed from analysis of experiences in Scotland and at other autonomous government levels in Spain, the FFC identifies the phases and actors involved in the adoption and implementation of gender budgeting. Drawn from practical experience, empirical analysis and conceptual analysis of feminist policy change, the FFC allows advocates of gender budgeting to strategise for the framing and promotion of gender budgeting, and allows policy decision-makers to identify the steps and components necessary to arrive at a genderaware budget. The following section uses the framework to assess historical developments in Scotland, with particular focus on the conceptual framing of gender budgeting and the interaction of critical actors.

\section{Framing gender budgeting}

Calls for feminist policy change in the mainstream of government business and across all policy areas can 'carry significant budgetary and fiscal consequences and are more complex to push through' (Annesley, 2010, p. 52). Advancing arguments for feminist policy change requires careful positioning and framing of gender budgeting as a strategic fit with other government priorities and narratives while maintaining a focus on transformative gender equality (O'Hagan, 2015). Therefore, the actions of local advocates and the responsiveness of government institutions to these demands are also of interest. Identifying appropriate tools and strategies for adoption and implementation presents significant challenges of advocacy and practicality. Advocates and receptive policymakers firstly need to adopt analytical and discursive approaches that recognise and challenge the gendered nature of pre-existing discourses. These fall into three types of frames: dominant government priorities and discourse; gender equality frames, setting out the government perspective on gender; and gender budgeting frames that structure how it is presented. For example, is gender equality framed as a matter of women's rights and emancipation and economic autonomy? Or is women's equality limited to economic participation and employment rates, instrumentalised in policy terms as a component of economic 
Figure 1: Framework of Favourable Conditions

\section{Phase One: Advocacy and Agenda-Setting}

- Pro-equality climate

- Commitment to gender mainstreaming

- Responsiveness and receptiveness to external drivers

- Political change and political opportunity structures

- Gender equality architecture

- Positive approach to governance

- Favourable economic conditions

- Understanding of budgetary processes

- Presence and pressure of women and feminist civil society organisations

\section{Phase Two: Formal Adoption}

- Clear conceptual framework for gender budgeting

- Engaged actors

- Officials (Finance)

- Politicians/parliamentarians

- Civil society

- Political will

- Positive institutional arrangements

\section{Phase Three: Implementation/Gender-Aware Budget}

- Evidence in practice

- Political leadership

- Strategy for continuity

growth? Is childcare provision, for example, essentially a matter of children's development or framed as also transforming gendered roles, supporting women's labour market participation? How is gender budgeting presented? Is it framed as a tool of gender mainstreaming or a transformative approach to the process of policymaking?

Also, it requires a reorientation in how gender is recognised as a policy problem and how gender is politicised as a legitimate political goal. In this way, gender budgeting is proposed as a policy response to women's unequal economic status and reflects its feminist transformative intent. 
As a consequence of the early advocacy of SWBG and its engagement with significant political actors, including successive finance ministers and the chair of the Scottish Parliament's Finance Committee, gender budgeting was accepted as a 'diagnostic' frame - that is, an acceptable policy response to acknowledging gender inequality in the policy process, and in budget formulation in particular.

The early approach of the Scottish Executive to operationalising this perspective was to 'equality proof' the budget, defined in 2000 as having a specific meaning in Scotland as 'the mechanism for linking the mainstreaming of equality in the policy process with the appropriate distribution of resources' (Scottish Executive, 2003, p. 35).

Intended to give clarity to policymakers, equality proofing the budget was presented as an essential component of the Executive's 'work on mainstreaming equality', a way of ensuring that equality considerations are taken into account in developing policies and 'essential ground work for equality proofing the budget' (Scottish Executive, 2003).

Social justice was the dominant government policy frame in the first two sessions of the Scottish Parliament (1999-2007), embedded in the overarching policy framework of successive governments. In 2002 the Scottish Executive presented objectives to 'tackle poverty, build strong, safe communities and create a fair, equal Scotland where rights for all is our byword' (Scottish Executive, 2002, p. 3). This political commitment to social justice continued with the Scottish Executive spending plans for 2003-6, Building a Better Scotland, introduced as plans for 'working to close opportunity gaps across Scotland' (Scottish Executive, 2002, p. 3). This was described later as a first attempt at using the spending plans to link targets across ministerial portfolios, with resource allocations set against specific proposals (Scottish Executive, 2004, p. 38).

The change of government in 2007 and the Scottish National Party's (SNP) Government Economic Strategy altered the dominant government frame, setting out the overarching purpose of government as 'creating a more successful country, with opportunities for all of Scotland to flourish, through increasing sustainable economic growth' (Scottish Government, 2007, p. 8).

Table 2 sets out the timeline of the changes in institutional arrangements and main actors, indicating the key documents containing significant discursive changes over the period from equality proofing to embedding equality budgeting. The detail is provided to highlight 
Table 1: Timeline of key actors, events and outputs for gender budgeting in Scotland 1999-2009

\begin{tabular}{|c|c|c|}
\hline Year & Actors and events & Outcomes \\
\hline 1999 & $\begin{array}{l}\text { Referendum on Scottish } \\
\text { Devolution }\end{array}$ & $\begin{array}{l}\text { Scottish Parliament and Scottish } \\
\text { Executive established }\end{array}$ \\
\hline 2000 & $\begin{array}{l}\text { Engender Women's Budget } \\
\text { Group (EWBG/SWBG) } \\
\text { established } \\
\text { Equality Proofing Budgets } \\
\text { [Policy] Advisory Group } \\
\text { (EPBPAG) established } \\
\text { EWBG seminar with Canadian } \\
\text { Commission }\end{array}$ & $\begin{array}{l}\text { Scottish Executive published first } \\
\text { draft budget (2000-1); EWBG } \\
\text { respond } \\
\text { Scottish Executive published } \\
\text { equality strategy Working } \\
\text { Together for Equality } \\
\text { The Equal Opportunities } \\
\text { Committee published } \\
\text { Mainstreaming Equality checklist } \\
\text { for MSPs }\end{array}$ \\
\hline 2001 & $\begin{array}{l}\text { Scottish Government Expert } \\
\text { Seminar on Gender Budgeting }\end{array}$ & $\begin{array}{l}\text { Seminar report and } \\
\text { recommendations }\end{array}$ \\
\hline 2002 & $\begin{array}{l}\text { EPBPAG commissions } \\
\text { research on budget process }\end{array}$ & \\
\hline 2003 & Scottish Parliament elections & $\begin{array}{l}\text { Coalition government } \\
\text { Budget research completed } \\
\text { Scottish Executive published } \\
\text { Gender Impact Analysis and the } \\
\text { Scottish Budget: Understanding the } \\
\text { Scottish Budgetary Process } \\
\text { Scottish Executive published } \\
\text { Equality Strategy Annual Report } \\
\text { Scottish Executive Draft Budget } \\
\text { 2004-5 contained equality } \\
\text { statements in spending portfolios }\end{array}$ \\
\hline 2004 & EPBPAG agrees pilot studies & Pilot studies completed \\
\hline 2005 & & Pilot studies published \\
\hline 2006 & $\begin{array}{l}\text { UK Government approves } \\
\text { Equality Act, introducing } \\
\text { gender equality duty }\end{array}$ & $\begin{array}{l}\text { EPBPAG does not meet for } \\
\text { eighteen months }\end{array}$ \\
\hline 2007 & Scottish Parliament elections & SNP form minority government \\
\hline 2008 & $\begin{array}{l}\text { EPBPAG becomes Equality } \\
\text { Budgets Advisory Group }\end{array}$ & \\
\hline 2009 & & $\begin{array}{l}\text { Scottish Government published } \\
\text { Equality Statement on the Draft } \\
\text { Budget, 2010-2011 }\end{array}$ \\
\hline
\end{tabular}


the considerable time that has passed and the multiple interventions with and between government and parliament and external actors that underpin the current state of development of gender budgeting in Scotland.

\section{Political opportunities and critical actors}

Political change has dominated Scottish politics for the last few decades. The long lead-in to devolution in 1999 was followed by a gradual evolution of powers dripping through from the Calman Commission into the Scotland Act, 2012, and - following the independence referendum in 2014 - resulting in the Smith Commission and Scotland Act, 2016. Gender equality has, arguably, not been a central feature of these developments, despite strong advocacy from organised feminist campaigning as a constant feature throughout (O'Hagan, 2016a).

As a form of disruption, gender budgeting seeks to undo the 'gendered patterning' of political institutions and norms (Mackay, 2014). Promoting this new and potentially transformative approach to public policy decision-making was, and arguably still is, an attempt to interrupt the traditional norms of economic decision-making to achieve more gender equal outcomes instead. As Scotland has been in a state of change for almost two decades, institutional change and new powers have provided successive entry points for the disruptive influence of SWBG and others.

The importance of the decision-making 'venue' and engagement with the core executive has been increasingly highlighted as essential to advancing gender equality policy (Annesley \& Gains, 2012; Annesley et al., 2014). SWBG has understood this dynamic from the outset in an approach that is characterised and driven by a focus on the budget process together with the essential engagement with finance officials and ministers.

The political will of elected members to commit to gender equality as a political priority is essential for developing a robust analysis and framing of gender equality and for establishing effective institutional arrangements to drive the necessary analysis. In Scotland, access to the newly established institutions proved relatively easy in the first instance given the personal, professional and political relationships that exist in a small country where activists often have multiple roles and identities (O'Hagan \& Gillespie, 2016).

SWBG has remained outside government while also being instrumental in creating and engaging in an elite policy network, the 
Equality and Budget Advisory Group (EBAG). Established by the Scottish Executive in 2000 as the Equality Proofing Budgets Advisory Group, EBAG is convened by the Scottish Government Equality Unit and comprises members from across government departments, including the Director of Budgets, the Office of the Chief Economic Advisor, the Analytical Services Division and policy departments. In addition to SWBG, external members offering advice and seeking to inform government on the process of integrating equality analysis in the budget process include the Equality and Human Rights Commission (EHRC), the Convention of Scottish Local Authorities and the Joseph Rowntree Foundation.

A distinctive characteristic has been the extent of parliamentary engagement in attempts to adopt gender budgeting in Scotland. Witnesses to the committee during its budget scrutiny included SWBG, EHRC, trade unions and women's organisations. At the same time, Ailsa McKay ${ }^{1}$ was the budget adviser to the committee for three of the budgets in the parliamentary session 2007-11. These external influences are clearly reflected in the focus on economic modelling and the Scottish Government's shift to integrate equality into the budget and economic strategy.

In 2010 the equality budget statement (EBS) noted the expansion of EBAG to include senior critical actors within government and their influence in EBAG and on parliamentary scrutiny, increasing the focus on gender equality in the content and formulation of economic policy:

Following on from the discussions with the Cabinet Secretary for Finance and Sustainable Growth, EBAG has engaged with the Office of the Chief Economic Adviser to discuss some of the underpinning issues around equality and the economy. In particular the discussion focused on issues relating to women's role and participation in the labour market, the formal and informal economy and the challenge of measurement and economic modelling for this. (Scottish Government, 2010a, p. 9)

${ }^{1}$ Ailsa McKay was a professor of economics at Glasgow Caledonian University, founder of the Women in Scotland's Economy (WiSE) Research Centre at Glasgow Caledonian University and co-founder of SWBG. 


\section{Discursive shifts and policy innovation: Equality budget statement}

In Scotland gender budgeting was first presented as supporting economic efficiency and more effective and targeted policymaking, in line with arguments from the new administration in 1999. SWBG resisted promoting gender budgeting as equalities mainstreaming, in part due to its concerns over the conceptual weaknesses of equalities mainstreaming and that the gender dimensions of inequality were occluded in the dominant social justice frame (McKay \& Gillespie, 2007; O'Hagan \& Gillespie, 2016). Arguably, the broad equalities frame has been operationalised as a generic approach of equivalence, rather than an analytical approach to addressing structural and intersectional discrimination experienced by women. Gender equality was not consistently or clearly articulated within the preferred approach of equalities mainstreaming. For a time, gender-specific policymaking focused largely on gender-based violence, until a more recent emphasis on women's economic status through labour market participation gained greater purchase, in part as a consequence of the change of government and discourse from 2007 and through the actions of specific advisers and activists.

In 2003 equality proofing was defined as 'equality budgeting' within the 'equalities mainstreaming', and not explicitly as gender equality. A sustained focus on economic modelling, and the steer from SWBG and EBAG to the Scottish Government to integrate equality into the budget and economic strategy, followed the advice from Elson (1999) to use medium-term economic frameworks, such as government spending plans and economic strategies, as a vehicle for advancing gender equality.

The shift from social justice to economic growth prompted a reorientation of SWBG's engagement. It moved away from the previous emphasis on effectiveness and efficiency and challenged the perceived deficiencies of an equalities mainstreaming approach that rendered gender analysis almost invisible in economic policy, advocating instead a more resolutely feminist economics perspective (O'Hagan \& Gillespie, 2016). This emphasis was amplified by gender equality advocates present within the institutional processes, including the renamed and regrouped EBAG as representatives of both SWBG and independent academic advisers. The resultant reorientation of policy is evident first in the creation of the EBS introduced by the Scottish Government in 2009, and then through later changes in 
government discourse on the relationship between advancing equality and economic policy.

In the years since, the EBS has sought to evidence the developing process of articulating how resourcing decisions are formulated in relation to broad equalities aspirations, as well as setting out government's spending on equalities activity. The EBS is not an exact match with the proposed tools of gender budgeting (Elson, 1999), but it is an important combination of statement of intent and reflection on how equality is conceptualised and, potentially, increasingly embedded in the Scottish budget process. There is no equivalent to the EBS in the other governments of the UK, nor is it the same as the equality impact or evaluation exercises conducted by other country and sub-national governments, such as the annual impact evaluation reports of the Government of Andalucía or the departmental analysis of the Austrian Government. A significant weakness of the EBS is that it remains more of a narrative accompaniment offering a post hoc analysis of government spending decisions rather than presenting an equality impact analysis of Scottish Government spending or revenue proposals, and reflecting an understanding of the effect of resource allocations for advancing gender equality. In its current form, it does not fall neatly into the categorisations of ex ante, concurrent or ex post as proposed by the OECD (2016).

Despite these weaknesses, on which SWBG continues to focus, including in the review of the Scottish budget process (Sept 2016 to June 2017), the EBS is evidence of the 'enabling environment' described in the OECD typology. It acts as a lens through which to view how arguments advanced by SWBG and feminist advocates in EBAG (often the same people) and, increasingly, external feminist and other organisations have produced demonstrable change in the discursive package from the Scottish Government, as argued below.

In early budget documents under the first Scottish Labour/Scottish Liberal Democrat coalition governments, first ministers made significant commitments to integrate equality analysis into the budget process (Scottish Executive, 2001, 2002). In 2009 the EBS marked a decisive step forward.

In its first iteration the EBS tentatively committed the Scottish Government 'to make spending plans in the light of equality considerations, and to develop ways of showing more clearly the links between evidence, policy, spending and equalities outcomes' (Scottish Government, 2009, p. 3). 
In 2010, following its scrutiny of the draft budget, the Equal Opportunities Committee of the Scottish Parliament set a clear direction for the Scottish Government:

the framework of economic analysis informing future spending plans should incorporate equality considerations, thus embedding equality within the mainstream budget process with a view to the Scottish Government applying equality impact analysis to the framework of economic modelling employed in determining the relevant range of the economic forecasts that in turn inform its future economic strategy. (Equal Opportunities Committee, 2011, p. 6)

Greater visibility of a growing policy focus on women began to emerge from 2010. The subsequent EBS reveals adoption by the Scottish Government of the arguments made by SWBG and the Equal Opportunities Committee:

We recognise that equality is an important driver of growth and that inequality detracts from our economic performance and our social wellbeing. We make clear in our Economic Strategy, the importance of increasing participation in the labour market, removing the structural and long standing barriers which limit opportunities and harnessing diversity and wealth of talent we have available to us as a nation. (Scottish Government, 2011 p. 10)

Women and the labour market were the focus of a 'Women's Summit' in 2012, structured around investment in women as a driver of economic growth and the significance of the care economy, including childcare as economic infrastructure. In 2012 the EBS succinctly but significantly conceded 'the limitations of economic models which fail to reflect the contribution of women's paid and unpaid employment' (Scottish Government, 2012, p. 6).

In autumn 2013 the context of the Scottish budget was one of enduring financial constraint and the impact of 'welfare reform' and austerity by the UK government. A resurgent equality narrative was resolutely framed as central to economic growth and recovery: 'Equality is an important driver of growth and inequality detracts from our economic performance and productivity' (Scottish Government, 2013, p. 8). 
While the EBS articulated concerns over the impact and causes of inequalities, there was a reduced focus on transformative approaches to budget setting and economic policy. In 2014, however, these concerns returned in the budget that carried the SNP Government from the independence referendum into a pre-election year, with a commitment to 'equality and social justice [that] reflects our understanding that equality is integral to our economic recovery, our social wellbeing and our programme of reform' (Scottish Government, 2014a, p. 3).

Scotland's Economic Strategy, which followed in March 2015, set the course for policy action and resource allocation to stimulate inclusive growth and tackle inequalities as a dual-track approach (Scottish Government, 2015).

\section{Key policy developments}

In the last ten years a number of significant policy shifts have been directly related to the efforts to introduce gender analysis in the budget process.

\section{Childcare}

Principal among the significant policy developments was the extension of publicly provided childcare, characterised as an economic imperative and integral to the economic and social infrastructure of Scotland (Campbell et al., 2013).

A long-held feminist demand for women's emancipation and for recasting gender relations has been the provision of affordable, accessible, flexible childcare. The White Paper on independence (Scottish Government, 2013) promoted the SNP approach to 'transformational childcare'. Continuing political commitment to the expansion of childcare is evident in the statement by Nicola Sturgeon upon becoming First Minster in 2014:

An extension of childcare on the scale we plan will require, not just revenue investment, but major capital investment in our education estate. Our flagship infrastructure project in this parliament has been the new Forth Bridge... I want to make one of our biggest infrastructure projects for the next parliament a different kind of bridge. I want it to be comprehensive childcare, giving our young people the best start in life and a bridge to a better future. (Sturgeon, 2014) 
In a small polity like Scotland, and arguably Ireland, there is greater access and a more proximate relationship between elected representatives, civil society organisations and activists. The rapid acceleration of childcare provision as a core area of government policy and spending commitment is directly traceable to the advocacy of WiSE, SWBG and members of EBAG, among others. This formulation, however, is a clear example of a classic public policy triangle of policy and political actors, academic analysis, and civil society pressure and advocacy for feminist policy change in the appropriate policy venue. Feminist economist advocates Campbell et al. (2013) advanced the transformative potential of decoupling childcare from the traditional framing as a women-friendly social policy, arguing instead for a combined economic and social policy to advance gender equality. Public investment in childcare, they argued, is beneficial to the economy as both capital and social investment in economic and social infrastructure that would expand the childcare estate and workforce, and increase labour market access for parents, particularly women, with long-term economic and social benefits.

Campbell et al. (2013) argued that, in an independent Scotland, revenue from the expanded tax base of all workers, including additional childcare workers, would be retained in Scotland and could be channelled into further investment in social infrastructure. In a follow-up analysis Lapniewska (2016) explored the multiplier benefits of the workforce expansion claims and found that, if the investment in the proposed physical infrastructure was distributed evenly across 2017-20, it could translate into an approximately 0.33 percentage point annual GDP rise, and the gradual investment in wages, expanded childcare services and investment in the skills of future childcare practitioners and managers would also contribute to a rise in GDP. Lapniewska found multiple employment benefits for women and men, as well as positive supply chain and multiplier effects from investment in social infrastructure.

Commitments made in the 2014-15 budget to fund the expansion of childcare to 1,140 hours annually by 2020 - building on the increase to 600 hours proposed in the Children and Young People Act, 2014 have sustained in subsequent budgets. It is an ambitious expansion plan, and arguments for investing in and valuing the childcare workforce, developing alternative modes of delivery, and securing parental choice and quality early-years care for children are all given voice in this political commitment (Scottish Government, 2017). However, the framing of economic emancipation, decoupling child- 
care and women's traditional caring roles, and locating childcare as an economic imperative has shifted in the budget documents. While still claimed as infrastructure investment, childcare expansion has most recently been articulated within the Education and Skills spending portfolio, with the emphasis on children and families in response to political pressure to close the attainment gap in education and support low-income families. The gender equality aim for the policy is the third claim and is focused on boosting women's labour market participation. From a feminist policy change perspective, this elision from infrastructure framing is of concern, especially since elsewhere in the budget documentation investment in infrastructure is not linked to the advancement of equality and has reverted to capital investment.

Undoubtedly, the budgetary commitment is significant, with a proposed allocation of $£ 60$ million in 2017-18 alone (Scottish Government, 2017). In 2015 the SNP's election manifesto estimated a spending commitment of $£ 439$ million in $2015-16$ to $£ 939$ million in 2020-1 (Fraser of Allander Institute, 2016a). In the current context the Scottish Government faces considerable pressure to honour this commitment at a time of shrinking budgets. It remains to be seen whether the capital boost from the UK 2017 spring budget (UK Government, 2017) will help with the costs. That the $£ 750$ million coming to Scotland through the infrastructure investment of the City Deals programme has not been integrated as a lever for encompassing equality issues, such as occupational segregation and underrepresentation in the Modern Apprenticeship (MA) programme, or including equality compliance conditions in public procurement suggests that links across government portfolios still need to be made more robust.

\section{Cross-portfolio examples}

The focus on childcare expansion is a positive case study of budget scrutiny, the locus of decision-making, and pressure points of influence in advancing feminist policy change through budget analysis. A less positive or dynamic story is the contraction in local government funding in particular and public sector wages in general. Over the last ten years, successive funding settlements to Scottish local authorities have been reducing, despite claims to the contrary from the Scottish Government. Some estimates suggest a year-on-year reduction of 1.3 per cent (Fraser of Allander Institute, 2016b), while in the Scottish budget for 2016-17 there was a 7.5 per cent real-terms cut. These cuts are in addition to restrictions on spending, meeting government 
commitments on staff-pupil ratios in schools and a nine-year freeze on the varying of council tax rates by local authorities. While these measures have attracted conditional funding for local authorities, overall budgets have declined and been diverted elsewhere, including the restructuring of finances for joint provision of community health and social care services. The consequent effects of this are highly gendered and include the withdrawal of services provided mainly by women as the majority workforce in local government, cuts to terms and conditions as services are outsourced, and an ongoing pay freeze following the UK Treasury approach with a persistent 1 per cent cap across public services in Scotland, which is the focus of trade union action (Russell, 2017).

Enduring occupational segregation across the labour market, especially in the government-funded MA vocational training scheme has been a consistent focus of gender budget analysis and external academic scrutiny. A sustained programme of research and analysis from the WiSE Research Centre has highlighted the imbalances in spending on male-dominated apprenticeships compared to skills areas where women prevail within overall frameworks that consolidate established patterns of occupational segregation (WiSE, 2013). The external analysis and internal advocacy through EBAG and other venues, including the 2012 Women's Summit already referenced, resulted in the Scottish Government's Commission for Developing Scotland's Young Workforce (Scottish Government, 2014b). Known as the Wood Commission, the inquiry sought to understand and address the imbalances in representation, and the under-representation of disabled people and black and minority ethnic apprentices in the programmes, which research for the EHRC had also highlighted. These prompts to generate and analyse data, formulate policy responses and spark action from public authorities have all had implications for resource allocation within institutions such as Skills Development Scotland, as well as within the funding regime for the MA programme.

\section{Favourable conditions for gender budgeting?}

In the context of the conditions for the successful adoption and implementation of gender budgeting proposed previously (O'Hagan, 2016b), Scotland's experience can be characterised as generally positive. By characterising the budget as a part of the policy process, and not an exercise conducted by finance officials at one remove from 
the policy process, gender analysis has informed policy discourse in shaping government priorities. The extent to which those priorities have been matched by resource allocations and spending decisions has been less positive.

As discussed throughout this article, the evidence of commitment to gender equality, albeit through the weaker conceptualisation of equalities mainstreaming, and the constellation of actors engaged in promoting and adopting gender budgeting indicate a level of sustained commitment to gender analysis in the budget process. The discursive shifts from efficient policymaking to an integral economic imperative of the advancement of gender equality and women's economic status have resulted in some specific developments in policy and resource allocation. Overall though, it cannot be said from the evidence of financial allocations that Scotland has a deeper gender-aware budget process with the goal of achieving greater gender equality as the starting point for policy and financial decisions.

\section{Conclusion}

Adoption and implementation of gender budgeting in Scotland has been a distinguishing feature of political change over the course of devolution in the last seventeen years. Through sustained engagement with successive Scottish Governments and the Scottish Parliament, SWBG and other stakeholders have maintained momentum and focus on progressing a transformative approach to decision-making and resource allocation in Scotland. Critical actors, inside and outside government, have been drawn into and engaged in the adoption and progress to implementation of gender analysis in the Scottish budget.

Despite a continuing tendency to instrumentalise women's labour market participation as a means to augment economic growth, rather than regarding women's equality as an intrinsic right, there have been important shifts in the framing of gender equality as central to the core business of government - managing resources for economic and collective well-being. Although a fully gender-aware budget remains elusive, these important developments in political engagement are clearly reflected in some changing government discourses. These have been articulated repeatedly in key government documents, including the EBS, which has to be recognised as one of a kind in the UK. Its value lies not only in the analytical content that shows endeavour on the part of the policy officials but also in its important symbolic value in articulating the commitment of government, and is therefore a 
means by which government can continue to be held to account for the advancement (or not) of gender equality in Scotland.

\section{References}

Acker, J. (1992). From sex roles to gendered institutions. Contemporary Sociology, 21 (5), 565-9.

Annesley, C. (2010). Gender, politics and policy change: The case of welfare reform under new labour. Government and Opposition, 45 (1), 50-72.

Annesley, C., Engeli, I., Gains, F., \& Resodihardjo, S. L. (2014). Policy advocacy in hard times: The impact of economic performance on gendering executive attention. West European Politics, 37 (5), 886-902.

Annesley, C., \& Gains, F. (2012). Investigating the economic determinants of the UK gender equality policy agenda. The British Journal of Politics and International Relations, 15 (1), 125-46.

Çağatay, N., Keklik, M., Lal, R., \& Lang, J. (2000). Budgets as if people mattered: Democratizing macroeconomic policies. Retrieved from http://www.chs.ubc.ca/lprv/PDF/lprv0482.pdf [4 July 2017].

Campbell, J., Elson, D., \& McKay, A. (2013). The economic case for investing in high-quality childcare and early years education. WiSE briefing paper, no. 5. Retrieved from http://www.gcu.ac.uk/wise/media/gcalwebv2/theuni versity/centresprojects/wise/WiSE_briefing_Nov13.pdf [20 March 2017].

Chappell, L. (2006). Comparing political institutions: Revealing the gendered 'logic of appropriateness'. Politics and Gender, 2 (2), 223-35.

Elson, D. (1995). Male bias in the development process. Manchester: Manchester University Press.

Elson, D. (1999). Gender budget initiative: Background papers. London: Commonwealth Secretariat.

Equal Opportunities Committee. (2011). 2nd report, 2011 (Session 3). Report on Scotland's spending plans and draft budget 2011-12 volume 2: Reports from other committees and the Scottish Commission for Public Audit. Retrieved from http://archive.scottish.parliament.uk/s3/committees/ finance/reports-11/fir11-02-vol2-01.htm\#ANNF [27 March 2017].

Figart, D. M. (2005). Gender as more than a dummy variable: Feminist approaches to discrimination. Review of Social Economy, 63 (3), 509-36.

Fraser of Allander Institute. (2016a). Scotland's budget-2016. Retrieved from https://www.sbs.strath.ac.uk/economics/fraser/20160913/ScotlandsBudget2016.pdf [23 March 2017].

Fraser of Allander Institute. (2016b). Fiscal issues facing local government in Scotland. Retrieved from https://www.sbs.strath.ac.uk/economics/fraser/ 20170310-Fiscal-issues-facing-Local-Government-in-Scotland.pdf [23 March 2017]. 
Himmelweit, S. (2002). Making visible the hidden economy: The case for gender-impact analysis of economic policy. Feminist Economics, 8 (1), 49-70.

Lapniewska, Z. (2016). Growth, equality and employment: Investing in childcare in Scotland. WiSE working paper series, no. 4. Retrieved from http:// www.gcu.ac.uk/wise/media/gcalwebv2/theuniversity/centresprojects/wise/98 178 per cent20WiSE per cent20BREIFING per cent20PAPER per cent204 per cent20August.pdf [27 March 2017].

Lovenduski, J. (1998). Gendering research in political science. Annual Reviews in Political Science, 1 (1), 333-56.

Mackay, F. (2014). Nested newness, institutional innovation, and the gendered limits of change. Politics \& Gender, 4, 549-71.

McKay A., \& Gillespie, M. (2007). Gender mainstreaming or 'mainstreaming gender'? A question of delivering on gender equality in the new Scotland. In M. Keating (Ed.), Scottish social democracy: Progressive ideas for public policy. Brussels: P.I.E. Peter Lang.

OECD. (2016). Gender budgeting in OECD countries. Retrieved from https://www.oecd.org/gender/Gender-Budgeting-in-OECD-countries.pdf [4 July 2017].

O'Hagan, A. (2015). Favourable conditions for the adoption and implementation of gender budgeting: Insights from comparative analysis. Politica Economica/Journal of Economic Policy, 2, 233-52.

O'Hagan, A. (2016a). Redefining welfare in Scotland - With or without women? Critical Social Policy, 36 (4), 1-23.

O'Hagan, A. (2016b). Challenging the norms: Gender budgeting as feminist policy change. In J. Campbell \& M. Gillespie (Eds), Feminist economics and public policy: Reflections on the work and impact of Ailsa McKay. London: Routledge.

O’Hagan, A., \& Gillespie, M. (2016). Gender budgeting in Scotland: Seeking transformative change through public spending. In J. Campbell \& $\mathrm{M}$. Gillespie (Eds), Feminist economics and public policy: Reflections on the work and impact of Ailsa McKay. London: Routledge.

O'Hagan, A., \& Klatzer, E. (forthcoming). Gender budgeting in Europe: Developments and challenges. London: Palgrave MacMillan.

Rubery, J. (2005). Reflections on gender mainstreaming: An example of feminist economics in action? Feminist Economics, 11 (3), 1-26.

Russell, G. (2017, March 24). PCS furious over pay cap on Scottish public sector pay. The National, p. 1

Scottish Executive. (2000). Investing in you. Retrieved from http://www.gov.scot/Resource/Doc/158164/0042800.pdf. [5 June 2017.]

Scottish Executive. (2001) Making a difference for Scotland: Spending plans 2002-03, 2003-04. Edinburgh: Scottish Executive.

Scottish Executive. (2002). Closing the opportunity gap scottish budget for 20032006. Edinburgh: Scottish Executive. 
Scottish Executive. (2003). Making progress: Equality annual report. Retrieved from http://www.gov.scot/Resource/Doc/1137/0034302.pdf [5 June 2017].

Scottish Executive. (2004). Building a better Scotland. Edinburgh: Scottish Executive.

Scottish Government. (2007). Government economic strategy. Edinburgh: Scottish Government.

Scottish Government. (2008). Draft budget 2009/10. Edinburgh: Scottish Government.

Scottish Government. (2009). Draft budget 2010/11: Equality statement. Edinburgh: Scottish Government.

Scottish Government. (2010a). Equality statement: Scotland's budget 2011-12. Edinburgh: Scottish Government.

Scottish Government. (2010b). Independent budget review: The report of Scotland's independent budget review panel. Retrieved from: http://www.gov.scot/Resource/Doc/919/0102410.pdf [27 March 2017].

Scottish Government. (2011). Equality statement: Scottish spending review 2011 and draft budget 2012-13. Edinburgh: Scottish Government.

Scottish Government. (2012). Equality statement: Scottish draft budget 2013-14. Edinburgh: Scottish Government.

Scottish Government. (2013). Equality statement: Scottish draft budget 2014-15. Edinburgh: Scottish Government.

Scottish Government. (2014a). Equality statement: Scottish draft budget 2015-16. Edinburgh: Scottish Government.

Scottish Government. (2014b). Commission for Developing Scotland's Young Workforce final report. Retrieved from http:/www.gov.scot/Topics/ Education/developingtheyoungworkforce/background/commissionreports esponse [4 July 2017].

Scottish Government. (2015). Scotland's economic strategy. Retrieved from http://www.gov.scot/Resource/0047/00472389.pdf [23 March 2017].

Scottish Government. (2016). Scottish budget: Draft budget 2017-18. Retrieved from http://www.gov.scot/Publications/2016/12/6610 [23 March 2017].

Scottish Government. (2017). A blueprint for 2020: The expansion of early learning and childcare in Scotland 2017-18 action plan. Edinburgh: Scottish Government.

Sharp, R. (2003). Budgeting for equity: Gender budget initiatives within a framework of performance oriented budgeting. New York: United Nations Development Fund for Women.

Sharp, R., \& Broomhill, R. (2002). Budgeting for equality: The Australian experience. Feminist Economics, 8 (1), 25-47.

Sturgeon, N. (2014). Nicola Sturgeon address to SNP conference. Retrieved from www.snp.org/media-centre/news/2014/nov/nicola-sturgeon-addresssnp-conference [4 July 2017].

UK Government. (2017). UK Government spring budgeting. Retrieved from https://www.gov.uk/government/topical-events/spring-budget-2017 [23 March 2017]. 
WiSE. (2013). How modern is the modern apprenticeship in Scotland? Retrieved from http://www.gcu.ac.uk/wise/media/gcalwebv2/theuniversity/ centresprojects/wise/A4\%20WiSE\%20Briefing\%20Paper\%20v3.pdf [4 July 2017]. 